\title{
Author Correction: Time-dependent memory transformation along the hippocampal anterior-posterior axis
}

\author{
Lisa C. Dandolo ${ }^{1} \&$ Lars Schwabe ${ }^{1}$
}

Correction to: Nature Communications https://doi.org/10.1038/s41467-018-03661-7, published online 23 March 2018

In the originally published version of this Article, the rightmost graph in Fig. $2 c$ was inadvertently replaced with a duplicate of the central panel. This has now been corrected in both the PDF and HTML versions of the Article.

Published online: 24 May 2018

\begin{abstract}
(c) (i) Open Access This article is licensed under a Creative Commons Attribution 4.0 International License, which permits use, sharing, adaptation, distribution and (C) reproduction in any medium or format, as long as you give appropriate credit to the original author(s) and the source, provide a link to the Creative Commons license, and indicate if changes were made. The images or other third party material in this article are included in the article's Creative Commons license, unless indicated otherwise in a credit line to the material. If material is not included in the article's Creative Commons license and your intended use is not permitted by statutory regulation or exceeds the permitted use, you will need to obtain permission directly from the copyright holder. To view a copy of this license, visit http://creativecommons.org/licenses/by/4.0/.
\end{abstract}

(๑) The Author(s) 2018

\footnotetext{
${ }^{1}$ Department of Cognitive Psychology, University of Hamburg, 20146 Hamburg, Germany. Correspondence and requests for materials should be addressed to L.S. (email: Lars.Schwabe@uni-hamburg.de)
} 